\title{
POLA LEMBAGA KEAGAMAAN DALAM MERESPON WABAH COVID-19
}

\author{
P-ISSN: 2085-4536 | E-ISSN: 2721-7183 \\ Link: https://jurnal-stidnatsir.ac.id/index.php/dakwah/article/view/36 \\ DOI : https://doi.org/10.38214/jurnaldawahstidnatsir.v2i01.36 \\ Dikirim: 01-05-2020 \\ Direview: 01-05-2020 \\ Diterbitkan: 06-05-2019
}

\author{
AHMAD MISBAHUL ANAM \\ misbahulanam@stidnatsir.ac.id \\ STID Mohammad Natsir, Indonesia
}

\begin{abstract}
ABSTRAK
Tujuan Penelitian: Penelitian ini bertujuan untuk mengungkap pola lembaga keagamaan dalam merespon wabah Covid-19. Metode Penelitian: Kualitatif. Hasil Penelitian: Terdapat pola yang sama dari masing-masing lembaga untuk menempatkan hasil Fatwa MUI sebagai pondasi pijakan, kemudian dilanjutkan dengan penerbitan himbauan yang lebih teknis oleh masing-masing lembaga. Himbauan tersebut mengajak seluruh komponen unit dibawahnya untuk menyiapkan berbagai hal yang memungkin, akibat dampak Civid-19. Ada satu implikasi yang berharga dari kasus ini, yaitu mulai berangsur-angsur menempatkan posisi MUI sebagai perekat dan penyatu ummat, khususnya dalam hal-hal yang bersinggungan dengan pemerintah. Jika pola hirarki menempatkan MUI sebagai dasar hukum dalam aspek yang luas, maka akan memudahkan persatuan umat kedepan. Pola seperti ini sebenarnya bukan kali pertama MUI mengambil peran dan lembaga mitra berpartisipasi, sudah banyak Fatwa yang telah diputuskan dan mendapat respon dukungan dari lembaga keagamaan. Tapi pada kali ini, karena fenomena masail fiqiyahnya berskala nasional, peran lembaga keagamaan juga semakin maksimal.
\end{abstract}

Kata kunci: Pola, fatwa, bayan. 


\section{PENDAHULUAN}

Fenomena global yang paling menarik untuk disikapi pada awal tahun 2020 adalah kasus Corona Virus atau lebih dikenal dengan Covid19. Kemunculanya diawali dari daerah Wuhan salah satu provinsi di Cina, dengan dugaan sementara akibat virus kelelawar. Setelah terjadi korban, dan dinyatakan virus ini kemudian dapat ditularkan melalui interaksi antar manusia, semua Negara, bahkan -boleh dibilang- seluruh warga dunia berbicara tentangnya, tak terkecuali lapisan bawah, juga anak-anak. Masing-masing Negara memiliki cara untuk mengantisipasinya, walaupun secara standar mengikuti protocol yang dibuat oleh lembaga kesehatan dunia WHO. Sampai saat ini, akibat yang ditimbulkan tidak lagi pada aspek kesehatan, tapi juga berimbas pada penurunan daya beli masyarakat akibat lumpuhnya dunia ekonomi. Bahkan, sudah mulai terdengar pula, banyak Negara di Eropa dan juga Amerika melakukan tuntutan hukum, berupa ganti rugi finansial akibta bobolnya anggaran suatu negara. Hal tersebut sebagaimana yang di suarakan oleh media nasional Jerman dan kemudian ikut diramaikan media masa yang ada. Mengapa mereka melakukan tuntutan? Karena Covid 19 telah menyedot anggaran negara, bahkan telah melumpuhkan berbagai sektor ekonomi, pendidikan dan transportasi.

Sementara korban telah berjatuhan, apakah yang sakit ataupun yang meninggal, vaksin untuk mengatasinya belum ditemukan. Virus ini telah bermigrasi melalui carier antar manusia, melewati negara dan benua. Seruan untuk melakukan jaga jarak secara sosial ataupun fisik (social / physical distancing) digemakan agar tidak ada lagi kerumunan. Sebagian negara telah menutup bandara, stasiun, mal-mal dan fasilitas umum. Pesta-pesta terpaksa ditunda ataupun dilakukan hanya untuk kalangan keluarga, sebagianya dibubarkan. Pesta perkawinan hanya dihadiri kalangan keluarga inti, tanpa pesta walimah sebagaimana biasanya. Penguburan mayat semakin menyedihkan, karena setiap kematian dipersepsikan harus ditangani ala korban covid 19.

Negara terpaksa mengeluarkan aturan dengan diterbitkanya Kepres No 11 tahun 2020 tentang penetapan kedaruratan kesehatan masyarakat Corona Virus Desease (Covid-19) yang wajib dilakukan penanggulangan sesuai peraturan. Kepres ini mulai diundangkan dalam lembar Negara sejak tangal 31 Maret 2020. Walaupun demikian sempat terjadi ke-tidak kompakan untuk saling mendukung, sebagaimana 
pemberitaan media antara kementerian kesehatan dan kementerian transportasi. Pada level pemerintah yang ada di bawah juga bergejolak, diwakili oleh suara beberapa kabupaten dan provinsi dengan cara melakukan lockdown terbatas berupa isolasi wilayah dengan tujuan melindungi kesehatan masyarakat.

Di kalangan masyarakat, khususnya umat Islam menjadi satu peristiwa yang sangat menyedihkan. Masjid, yang biasa ramai dikunjungi dan dilaksanakan shalat lima waktu dan shalat Jum'at menjadi tidak lagi mudah untuk ditemukan. Bahkan yang terdengan dari Masjid-masjid hanya suara Adzan dengan tambahan "Shalatlah kalian dirumah". Masyarakat semakin gaduh, karena sampai Jum'at ke-tiga masyarakat Muslim tidak bisa melakukan Shalat Jum'at, sementara keyakinan mengatan, "barang siapa tidak Shlat Jum'at tiga kali maka dipandang seseorang- telah Kafir".

Himbauan pemerintah dirasakan belum mampu memenuhkan kondisi spikologis keagamaan masyarakat, karena himbauan tersebut telah memasuki atau mengusik peristiwa keagamaan yang sangat khas. Sementara jika masyarakat tidak mematuhi himbauan tersebut, dikawatirkan penularan akan semakin meluas seiring dengan interaksi masa yang juga semakin massif dan mudah karena pertemuan yang dekat. Tentu hal ini juga dirasakan oleh lembaga keagamaan, bagaimana lembaga-lembaga ini melakukan antisipasi dan edukasi ke masyarakat sebagai otoritasnya. Alasannya jelas, "menyelamatkan satu jiwa, sama dengan menyelamatkan seluruh kehidupan". Lembaga keagamaan memiliki tanggung-jawab untuk menerjemahkan pesan tersebut agar masyarakat lebih siap, karena ada aspek ibadah yang harus ditinggalkan diantaranya adalah memindahkan shalat ke rumah. Bagi masyarakat tumbuh keyakinan, toh kematian akan datang dimanapun dan dalam kondisi apapun. Begitulah argument yang sering disuarakan oleh masyarakat. Bagi mereka, masjid tidak boleh tutup dari kegiatan ibadah.

Sementara otoritas pemerintah yang diwakili BNPB melalui situs resminya, menetapkan Status Keadaan Tertentu Darurat Bencana Wabah Penyakit Akibat Virus Corona di Indonesia berlaku selama 32 hari terhitung sejak tanggal 28 Januari - 28 Februari 2020. Diperpanjang dengan Surat Keputusan Kepala BNPB Nomor 13 A tahun 2020 tentang Perpanjangan Status Keadaan Tertentu Darurat Bencana Wabah Penyakit akibar Virus Corona di Indonesia yang berlaku selama 91 hari terhitung 
sejak tanggal 29 Februari - 29 Mei 2020․ Artinya, Ramadhan dengan segala amaliyahnya, I'dul Fitri dan tentunya pulang kampung akan tidak bisa lagi dilakukan. Kondisi seperti ini tentu tidak mudah untuk diterima oleh masyarakat, prokontra akan terjadi, karena ada banyak aspek yang bersinggungan dengan aktivitas keagamaan. Lembaga keagamaan memiliki peran yang sangat vital sebagai lembaga konsolidasi, menjembatani antara aturan Negara dan idealisme keagamaan masyarakat.

Penelitian ini akan memberikan perhatian terhadap himbauan lembaga-lembaga keagamaan Islam terkait dengan fenomena Covid-19, sebagai bentuk tanggung jawab dan tuntutan nilai-nilai yang diperjungkan sebagai lembaga pembina masyarakat. Penelitian ini untuk mengetahui tentang pola komunikasi lembaga keagamaan tentang hal tersebut dalam bentuk Fatwa, himbauan, panduan dan lain-lain. Selanjutnya penelitian ini akan mengkatagorikan pola-pola tertentu dalam himbauan lembaga keagamaan dari sisi konten isi, media yang digunakan, jama'ah yang dituju, tujuan disampaikan dan ruang lingkupnya. Dari usaha tersebut diharapkan akan ditemukan pola yang khas dari masing-masing lembaga.

Pada penelitian ini pendekatan yang digunakan adalah pendekatan komunikasi masa melalui media berupa produk Fatwa, Himbauan, Bayan dan Pernyataan Sikap dalam bentuk lembar. Selanjutnya data tersebut akan diuraikan secara panjang lebar melalui model kualitatif. Data-data diperoleh melalui situs atau portal masing-masing lembaga yang juga di kutip oleh media cetak dan on-line serta kiriman dokumen dalam bentuk whatsapp kepada kalayak umum. Produk lembaga tersebut kemudian dibaca, dikatagorikan, difahami dan dianalisa sehingga ditemukan suatu pola tertentu yang khas sebagai ciri suatu lembaga keagamaan terkait bagaimana mereka merespon fenomena ini.

Yang dimaksud dengan pola disini sejatinya adalah proses komunikasi dalam masyarakat terkait dengan struktur dan lapisan (layer) maupun ragam budaya dan proses-proses sosial yang ada di masyarakat tersebut, serta tergantung pula pada adanya pengaruh dan kelayakannya, baik secara individu, kelompok, ataupun masyarakat luas. Sedangkan substansi bentuk atau wujud komunikasi ditentukan oleh (1) pihak-pihak yang terlibat dalam komunikasi (komunikator dan khalayak), (2) cara yang ditempuh, (3) kepentingan atau tujuan komunikasi. (4) ruang lingkup yang

\footnotetext{
${ }^{1}$ bnpb.go.id
} 
melakukannya, (5) saluran yang digunakan, dan (6) isi pesan yang disampikan. Sehubungan dengan itu, maka kegiatan komunikasi dalam masyarakat dapat berupa komnikasi tatap muka yang terjadi pada komunikasi interpersonal dan kelompok serta kegiatan komunikasi yang terjadi pada komunikasi masa ${ }^{2}$.

\section{HASIL DAN DISKUSI}

Sampai pada bulan April 2020 ini, Covid-19 sudah tidak lagi menjadi fenomena lokal yang khas di kawasan Wuhan Cina yang dijadikan bahan berita di seputar dunia kesehatan. Kota-kota dunia di wilayah Eropa, Timur Tengah, Afrika, Amerika, Rusia dan Asia berkejaran melaporkan berita yang menyedihkan. Korbanya dalam artian daerah penyebaran dari Covid-19 sudah meng-global, menjadi pandemi setiap negara bahkan sudah mewabah sampai daerah pedesaan yang jauh dari ibu kota negara. Apa sebab? Perpindahan dan interaksi manusia menjadi sarana penyebarannya, sementara keperluan untuk bepergian adalah ciri manusia hidup. Pergerakan adalah kebutuhan yang tidak bisa dihentikan, sekali berhenti maka akan mempengaruhi kondisi sosial. Pemerintah memiliki peran yang sangat vital dalam usaha menghentikan perpindahan manusia walaupun memiliki resiko berhentinya layanan publik dan ekonomi. Tapi jika dibandingkan dengan kondisi kesehatan warga, kelihatanya keuntungan ekonomi bisa ditunda dan seluruh perhatian difokuskan pada penanganan Covid-19. Pemerintah melalui lembaga Badan Nasional Penanggulangan Bencana melakukan langkahlangkah awal mengantisipasi Covid-19 untuk memberikan panduan yang diperlukan bagi masyarakat.

Pada edaran yang kedua, BNPB mengeluarkan pernyataan tentang Perpanjangan Status Keadaan Tertentu Darurat Bencana Wabah Penyakit Akibat Virus Corona di Indonesia yang berlaku selama 91 hari terhitung sejak tanggal 29 Februari - 29 Mei 2020.

Menyusul kemudian lembaga keagamaan Islam melakukan respon dengan ikut menerbitkan himbauan, terutama kepada anggota dan jama'ah. Tercatat dari sisi tanggal respon atas fenomena ini, untuk yang pertama dikeluarkan oleh Dewan Masjid Indonesia (DMI) dalam bentuk

\footnotetext{
${ }^{2}$ Burhan Bungin, Sosiologi Komunikasi, Kencana, Jakarta, 2008, cet. Ke-3, hlm. 67
} 
membuat berupa famlet dengan konten Himbauan sanitasi dan siaga Covd - 19 DMI tertanggal 2 Maret 2020. Selain itu, Pimpinan Pusat DMI juga mengumumkan Surat Edaran kedua untuk mencegah penyebaran Covid-19 Nomor : 061/PP DMI/A/III/2020 pada Kamis, 19 Maret 2020. Isinya terkait hal teknis soal perlunya menjaga kesehatan jama'ah Masjid dari Covid-19 dan petunjuk teknis bagaimana melakukan pencegahan terhadap Masjid ${ }^{3}$.

Majlis Ulama Indonesia (MUI) mengeluarkan pernyataan terkait Covid-19 yang tertuang dalam bentuk Fatwa No 14 tahun 2020 oleh Bidang Fatwa pada Senin, 21 Rajab 1441H/16 Maret 2020M yang berisi tentang. "Penyelenggaraan Ibadah dalam situasi terjadi wabah Covid-19"4. Menyusul kemudian Persatuan Islam (Persis) mengeluarkan himbauan pada 21 Maret 2020 berupa surat himbauan tentang antisipasi penyebaran virus Corona ${ }^{5}$. Pimpinan Pusat (PP) Muhammadiyah juga membuat Surat Edaran Nomor 02/EDR/I.0/E/2020 tertangal 24 Maret 2020 tentang tuntunan ibadah dalam kondisi darurat COVID-19. Dalam edaran itu, Muhammdiyah menyebut jika wabah virus corona masih berlangsung hingga bulan Ramadhan dan Syawal. Sedangkan lembaga Al-Irsyad mengeluarkan Bayan al-Irsyad tanggal 30 maret di tandantangani Ketua Majlis Da'wah dan Sekjen organisasi.

Surat edaran PBNU ${ }^{7}$ bernomor 3953/C.I.034/04/2020 tersebut ditandatangani pada 3 April 2020. Ada tiga penjelasan dalam surat edaran tersebut. Berikut ini selengkapnya: Sebagai ikhtiar untuk menahan laju dan memutus mata rantai sebaran Covid-19, sebelum PBNU telah menerbitkan Surat Instruksi nomor 3945/C.I34/03/2020 tentang protocol $\mathrm{Nu}$ Peduli Covid-19 dan surat Instruksi Nomor 3952/C.I34/03/2020. Sebagai upaya lanjut, khususnya menyambut dan melaksanakan peribadatan di bulan Ramadhan dan Hari Raya Idul Fitri 1441 Hijriah. Berikutnya yang juga mengeluarkan himbauan dalam bentuk "Pernyataan Sikap" yang ditandatangani pada 15 April 2020 adalah Dewan Da'wah Islamiyah Indonesia ${ }^{8}$. Dalam maklumatnya, terkait aspek

\footnotetext{
${ }^{3}$ https://dmi.or.id

${ }^{4}$ https://mui.or.id

${ }_{6}^{5} \mathrm{https}: / /$ persis.or.id

${ }^{6} \mathrm{https}$ ://www.alirsyad.or.id

${ }^{7} \mathrm{https}: / /$ www.nu.or,id

${ }^{8}$ https://dewandakwah.or.id
} 
praktek ibadah organisasi ini mengembalikan kepada putusan Fatwa MUI, aspek lain lebih pada motivasi untuk terus melakukan pendampingan ummat dengan kegiatan da'wah, semampu yang dapat dilakukan.

Sedangkan pada aspek isi pesan, bisa dikatagorikan menjadi empat sub bahasan ; aspek ke-Islaman, ke-Indonesiaan, aspek kemanusiaan dan aspek kelembagaan. Keempat aspek tersebut untuk menggambarkan bahwa lembaga keagamaan dalam wilayah Indonesia memiliki kesadaraan yang sama walaupun berbeda dalam menuangkan dalam bahasa. Aspek ke-Islaman dalam arti bahwa lembaga keagamaan perlu menuangkan pesan-pesan ideologis transendenya untuk menyapa, atau mungkin dengan bahasa yang lebih vulgar ingin menenangkan kegelisahan anggota lembaga atau masyarakat, karena menyangkut hal kondisi tertentu tentang pelaksanaan ibadah. Himbauan pemerintah untuk "jaga jarak" berimplikasi pada praktek shalat jama'ah di Masjid, shalat Taraweh, Tabligh Akbar, Majlis Ta'lim, ziyarah kubur dan juga aktivitas yang berkenaan dengan Hari Raya I'edul Fitri. Lembaga perlu memberikan panduan kepada masyarakat agar mereka tenang dalam melaksanakan ibadah dalam kondisi dharurat.

Pada aspek ke-Indonesiaan, terlihat bahwa himbauan lembaga keagamaan maupun fatwa dalam rangka memberikan perhatian terhadap kesehatan semua orang. Kepentingan dari himbauan ini tidak saja untuk memberikan ketenangan kepada jama'ah tapi sejatinya adalah untuk keseluruhan warga negara. Bahwa seluruh warga memiliki tanggungjawab yang sama, yaitu menjaga keehatan bersama. Aspek ini, juga sejalan dengan aspek kemanusiaan yang diterjemahkan dengan menjadikan unit sosial dalam lembaga keagamaan terlibat lebih intens dalam aksi-aksi konkrit dilapangan. Aksi ini didorong oleh semangat ta'awun ala birri (menolong terhadap kebaiakn) dan juga doktrin agama "sebaik-baik manusia adalah manusia yang memberikan manfaat bagi orang lain". Seorang Muslim dengan sendirinya, baik saat menjadi warga negara ataupun warga dunia adalah suatu entitas sosial yang berusaha menampilkan kemanfaatan. Pada aspek kelembagaan, keterlibatan lembaga dalam berbagai aspek ini sejarinya adalah penerjemahan visi-misi organisasi yang diilhami oleh nilai-nilai agama. Jaringan kelembagaan digunakan untuk menerjemahkan putusan organisasi, layaknya negara memberikan tugas kepada unit-unit strukturalnya. 
Dari sisi isi pesan, MUI dengan kapasitasnya sebagai perkumpulan ulama membuat himbauan dalam bentuk Fatwa yang berisi tentang pertimbangan hukum, kondisi lapangan dan putusan fatwa yang didalamnya dimungkinkan koreksi jika ditemukan alasan yang baru. Dalam pertimbangan hukum, dasar diterbitkanya fatwa adalah mengacu pada aspek penanggulangan dari sisi keagamaan setelah melihat argumentasi lembaga yang berwenang yaitu WHO bahwa virus ini adalah wabah pandemi yang menular. Selain itu, sebagai dasar putusannya, fatwa ini juga memberikan pertimbangan dengan memaparkan ayat-ayat dan hadist yang terkait dengan musibah. Tujuanya untuk mengingatkan kaum muslimin dan juga para penentu kebijakan saat harus menghadapi dan memutuskan. Selain itu, ada juga bahan pertimbangan, bagaimana kaum Muslimin harus melaksanakan tuntutan syariat, tata cara pelaksanaan suatu ibadah, sementara dihadapkan atau terhalang oleh sesuatu hal, dalam hal ini wabah Covid-19.

Dalam putusannya, fatwa ini mengingatkan bahwa menjaga kesehatan adalah menjaga tujuan pokok beragama (al-abwal al-khamsab). Pandangan ini memberikan satu perhatian, bahwa kehidupan menjadi satu perhatian serius menurut pandangan keagamaan, karena dengan hidup banyak aktivitas bermanfaan yang bisa dihasilkan. Maka, jikalah fatwa ini memberikan kelonggaran bahkan suatu keharusan untuk tidak melaksanakan satu kewajiban ibadah, tujuannya untuk menjaga seseorang tetap dalam kondisi sehat. Mengapa? Karena menurut dunia sains kesehatan, interaksi dengan banyak orang akan memungkinkan seseorang tertular virus ini. Kondisi sakit, tentunya akan membuat posisi seseorang tidak bisa memaksimalkan aktivitas dengan sempurna. Artinya, jika seseorang tidak melaksanakan ibadah dimasjid, bukan diartikan takut mati, karena mati dimanapun. Tapi ini adalah satu usaha, agar kehidupan tetap berjalan dan bisa memberikan manfaat lebih banyak lagi. Inilah dasar fatwa ini, dan juga himbauan dari lembaga-lembaga keagamaan, walaupun dengan bahasa yang berbeda dan lebih pendek.

Bagi NU diantara tujuan himbauan adalah untuk memutus mata rantai penyebaran virus lebih luas. Demikian juga dengan lembaga keagamaan Muhammadiyah juga menekankan pentingnya memperhatikan berbagai petunjuk dan protokol yang ditentukan oleh pihak berwenang dalam upaya mencegah penyebaran Covid-19. Kedua lembaga ini bahkan memerintahkan kepada lembaga otonom yang terkait dengan kesehatan 
agar memaksimalkan posko-posko kesehatan dan rumah sakit yang dimiliki oleh lembaga untuk ikut serta mensukseskan agenda pencegahan ini.

Pimpinan Pusat Al-Irsyad dalam maklumatnya menekankan untuk memahami karakter agama Islam adalah tawazun (seimbang) dan tawassuth (pertengahan), sebagai bingkai gerak dan sikap terhadap mewabahnya virus Corona di tengah masyarakat. Mengajak segenap pengurus dan anggotanya, beserta umat Islam, untuk tidak terjebak dalam sikap ifrath (melampaui batas) dan tafrith (meremehkan). Seimbang dan pertengahan, seperti yang diajarkan Rasulullah Shallallahu Alaihi wa Sallam, "Ikatlah untamu, lalu bertawakkal-lah" (HR. Ibnu Hibban). Upaya Rasional tidak boleh melupakan upaya memperkuat hubungan manusia dengan Allah Ta'ala, baik dengan doa, dzikir, sabar, dan tawakkal. Upaya ini juga tidak boleh melupakan pada upaya rasional (sunnatullah).

Dalam risalah himbaunnya, terdapat kesamaan antara MUI dan Al-Irsyad, yaitu dalam mengambil sikap putusan sebagaimana kisah pada masa Khalifah Umar bin Al Khaththab Radhiyallahu 'Anhu saat menghindari kota yang dilanda wabah, walaupun tidak mencantumkan teks hadistnya secara detail. Sedangkan DMI himbauannya lebih mengarah pada aktivitas praktis di dalam Masjid, terkait dengan menjaga kebersihan masjid, kebersihan karpet, tempat wudhu, bagi jama'ah untuk membawa sajadah jika ke Masjid. Ditambahkan pula, agar bagi jama'ah yang sakit demam, batuk, ada gejala flu agar melaksanakan shalat di rumah. DMI termasuk lembaga keagamaan pertama yang mengeluarkan himbauan terkait bahaya corona, bahkan lebih awal dibandingkan BNPB sendiri. Mereka mengeluarkan himbauan dikususkan kepada Masjidmasjid sebagai domain program mereka, dan surat himbauan itu ddesain ulang dalambentuk famplet yang mudah dibaca oleh masyarakat Masjid.

Sedangkan lembaga Persis yang didirikan oleh A. Hasan dalam himbauannya, menekankan kepada masyarakat untuk senantiasa menyikapi segala situasi dan kondisi sesuai dengan petunjuk ajaran Islam. Termasuk tuntunan agar berikhtiar dalam mencegah penyebaran wabah penyakit dengan usaha lahiriah secara maksimal dengan tanpa mengurangi keyakinan yang kokoh tentang ketetapan qadha dan qadar Allah SWT. Meningkatkan kesadaran dan kepedulian dengan mengikuti panduan dan protokoler tindakan preventif dalam melakukan berbagai aktifitas untuk 
memutus mata rantai penyebaran virus. Seluruh warga Jamiyah dihimbau agar menghindari aktivitas dan acara yang mengumpulkan orang banyak, termasuk aktifitas ibadah shalat berjamaah di mesjid jami' dan kajiankajian, akan tetapi digantikan kegiatan ibadah dan kajian di internal keluarga dengan terus menjaga dan memantau kesehatan anggota keluarga ataupun tetangga dekat.

Sedangkan Dewan Da'wah Islamiyah Indonesia membuat surat pernyataan sikap yang intinya adalah agar masyarakat mematuhi Fatwa MUI dan juga aturan yang telah dikeluarkan oleh otoritas pemerintah. Dalam pernyataan sikapnya, Dewan Da'wah juga mengajak masyarakat untuk menjadikan musibah ini sebagai bahan pelajaran dan renungan betapa lemahnya manusia ini. Untuk itu, lembaga ini mengajak masyarakat untuk selalu berdoa dan menyandarkan diri mereka kepada Allah. Ditambahkan pada surat pernyataan ini perlunya pemerintah Republik Indonesia untuk waspada dan mengantisipasi usaha-usaha pihak asing untuk menjadikan peristiwa Covid-19 sebagai pintu masuk untuk mengintervensi dan mengeksploitasi ketahanan kita sebagai bangsa melalui pembelian obat dan bantuan tenaga serta peralatan medis. Dalam pernyataan sikap tersebut, lembaga ini juga memberikan support kepada pemerintah bahwa kita memiliki kemampuan untuk mengatasi hal tersebut.

Terkait dengan konten bimbingan ibadah khususnya Shalat Jum'at masig-masing lembaga memiliki pandangan yang sama sebagaimana pernyataan MUI. Dimana penghentian atau pembatasan pelaksanaan sholat Jumat dan berjamaah di masjid sesuai dengan situasi, kondisi, dan instruksi pemerintah setempat dan mengacu kepada edaran masingmasing lembaga. NU, Muhammadiyah, Al-Irsyad, selain menguatkan Fatwa MUI, dalam pernyataan mereka masing-masing juga menambahkan argumen fiqhiyah. Hanya DMI dan Dewan Da'wah yang tidak membuat Fatwa atau masuh dalam aspek fiqhiyah, tetapi mengembalikan dan menyandarkan kepada Fatwa MUI. Hal ini juga dikarenakan, masingmasing lembaga da'wah menjadi anggota dalam Majlis Fatwa MUI.

Tambahan yang sama-sama disuarakan dalam himbauan lembaga keagamaan adalah mengajak secara khusus kepada jama'ah lembaga tersebut dan secara umum kepada masyarakat agar senantiasa meningkatkan kualitas dan kuantitas ibadah individual dan keluarga terutama ibadah sunnah di rumah. Hal ini dilakukan sebagai usaha atau 
ikhtiar ruhiyah- imaniyah dengan cara memperbanyak ibadah sunnah, tilawah Al Qur'an, berdzikir dan berdo'a sesuai dengan tuntunan Sunnah Nabi SAW.

Dalam surat edarannya lembaga seperti NU, Muhammaduyah dan Persis, juga menekankan kepada lemabaga dibawahnya agar membentuk Satgas terhadap Pandemi Covid 19 berikut Call-centernya. Hal ini dilakukan sebagai bentuk layanan. Sedangkan lembaga seperti Dewan Da'wah menugaskan lembaga perwakilan daerah dan Laznas-nya untuk turut serta meringankan beban hidup dimasyarakat. Dalam laporanya sudah terlaksana di 18 provinsi kegiatan pembagian sembako dan penyemprotan disinfeksi sebagai usaha pencegahan.

Dalam penelitian ini ditemukan satu alur yang sama dalam pembuatan surat himbauan yaitu menunggu pernyataan pemerintah terlebi dahulu dan dalam hal ini diwakili oleh Badan Nasional Penanggulangan Bencana. Hal ini berdasar pada penaggalan surat yang tertera pada masing-masing himbauan lembaga. Perbedaan yang kelihatan adalah soal penamaan pada surat tersebut : Himbauan (DMI), surat instruksi (NU), surat maklumat (Muhammadiyah), Bayan tentang Covid19 (Al-Irsyad), Surat Himbauan (Persis) dan Surat Pernyataan Sikap (DDII). Penyebutan ini memiliki kaitan dengan budaya organisasi yang berkembang di lembaga tersebut.

Terkait dengan muatan pesan, yaitu bentuk pesanya masingmasing lembaga memiliki penamaan yang berbeda-beda. MUI menggunakan term Fatwa, tentu ini bisa dimaklumi kerena memang lembaga ini dari awal pendirianya dimaksudkan sebagai advokasi terhadap kondisi umat. Apakah advokasi dalam hal aliran dan nilai-nilai yang rusak, atapun terhadap nilia-nilai global sperti liberalisme, sekularisme dan pluralisme. Dari sisi pesan, penyebutan Fatwa dalam fenomena Covid-19 karena ada aspek keyakinan yang harus didudukkan dalam pelaksanaan lapangan akibta Covdi-19. Seperti soal pelaksanaan Shalat berjama'ah ke Masji, Shalat Jum'at dan Tarawih. Fatwa ini juga dikeluarkan setelah dilakukan pembahasan oleh unit khusus yaitu Majlis Fatwa. Bahkan dalam pembahasanya MUI juga mengajak para pakar dibidangnya unutk ikut memberikan masukan dan paparan, sehingga bahan-bahan dari para ahli bisa dijadikan bahan dalam rangka menentukan produk Fatwa. 
Lembaga NU menyebutnya dengan Instruksi Pimpinan Pusat sebagai nama dari surat yang diedarkan. Istilah ini menggambarkan pada organisasi pemerintah yang menekankan pada aspek kataatan pada perintah atau aturan untuk dilaksanakan yang jika tidak dilakukan makan akan ada hukuman. Bentuk ini mungkin pengaruh patronasi lembaga yang diurus oleh para Kiyai, dimana ada hubungan santri dan guru yang kuat. Bahkan ada kecondongan menempatkan senior, dalam hal ini instruksi pimpinan sebagai bentuk ketaatan mutlak. Istilah ini juga mewakili budaya organisasi yang berlaku dalam kehidupan para Kiyai dalam budaya kultural yang kuat, antara atasan dan bawahan.

Muhammadiyah dan Persis menggunakan sebutan Himbauan dalam surat edarannya. Sebagaimana penjelasan KBBI, Himbauan adalah panggilan -mungkin maksudnya adalah- lembaga memanggil seluruh organ dan jamaa'ah Muhammadiyah untuk ikut serta memberikan perhatian terhadap fenomena yang terjadi. Dalam perspektif khalayak umum, himbauan mengindikasikan lebih terbukanya hubungan organisasi dengan jama'ah dan unit-unit lembaga. Ada semacam kondisi dimana antara organisasi dan anggota bisa saling memahami

Sedangkan Al-Irsyad menggunakan term Bayan, yang biasa digunakan dalam perbincangan keagamaan. Penggunaan ini memberikan gambaran yang kuat, walaupun kelihatannya fenomena Covid-19 adalah persoalan duniawi, tapi sejatinya penanganannya bisa masuk dalam diskusi keagamaan, bahwa cenderung sangat ideologis. Sebutan ini juga mengindikasikan kekuatan lembaga ini pada aspek-aspek agama yang sangat ketat. Ada semacam keinginan budaya organisasi yang kuat bahwa lembaga adalah entitas yang berusaha memberikan pengaruh terhadap tersebarnya nilai-nilai budaya Islam ditengah masyarakat.

Dalam himbauannya, Dewan Da'wah menyebut surat edaranya dengan Surat Pernyataan Sikap. Ada pesan yang kuat, bahwa himbauan ini tidak saja menyinggung soal keumatan tapi juga ke-Indonesiaan. Mungkin sebutan ini juga dipengaruhi kelahiran lembaga ini, sebagai representasi sebagian umat Islam bahwa ada aspek kenegaraan yang perlu diperhatikan. Diksi "Pernyataan Sikap" menjadi semacam bentuk kata peringatan kepada otoritas pemerintahan untuk memberikan perhatian yang besar terhadap fenomena yang terjadi. Maka dalam pernyataan sikap tersebut diselipkan kata-kata, "agar pemerintah Republik Indonesia untuk waspada dan mengantisipasi usaha-usaha pihak asing untuk menjadikan 
peristiwa Covid-19 sebagai pintu masuk untuk mengintervensi dan mengeksploitasi ketahanan kita sebagai bangsa melalui pembelian obat dan bantuan tenaga serta peralatan medis". Ada kesan diksi ini, bahwa lembaga memberikan perhatian yang sangat kuat terhadap aspek-aspek politik kenegaraan dan ke-Islaman yang kuat. Satu pesan nilai yang tulus bahwa lembaga Islam juga sangat peduli terhadap kepentingan bersama sebagai bangsa.

Untuk media pesan, semua lembaga menggunakan teks pesan dalam bentuk tulisan dan disebarkan melalui situs web masing-masing. Seluruh lembaga juga membagi (share) surat putusan lembaga terkait Covid-19 melalui media daring yang tersekmentasi dalam bentul group Whatsapp, facebook, twitter dan IG. Bahkan masing-masing anggota group juga masing membanginya kepada kawan-kawan yang memiliki hubungan emosional dengan lembaga. Untuk meluaskan surat himbauannya, lembaga keagamaan ini mengirimkan teksnya kepada media cetak, televisi dan media non-cetak. Lembaga-lembaga tersebut juga mencantumkan himbauannya melalui situs resmi lembaga, sehingga mudah diakses setiap saat.

Sebagai sebuah panduan, himbauan lembaga memang terasa ada dampaknya bagi masyarakat walaupun masih banyak hal-hal yang perlu diklarifikasi terutama oleh pemerintah dan MUI. Pokok persoalannya adalah pada aspek idelogis keagamaan dan juga nilai-nilai kultur yang telah menjadi bagian dari masyarakat. Ada psikologis kejiwaan masyarakat, saat mendapati satu fenomena yaitu mengapa pasar, Mall masih buka? Sementara Masjid dipaksa tutup. Dua entitas ini sama-sama tempat berkumpulnya manusia. Dewan Kemakmuran Masjid banyak yang mengalami penurunan mental karena sebagai pengurus Masjid tidak lagi bisa meramaikan pusat pembinaan masyarakat. Padahal, untuk menumbuhkan minta warga untuk mengunjungi dan ikut terlibat meraimaikan Masjid telah dirancang puluhan tahun. Tapi, tiba-tiba pembinaan itu runtuh dengan sekejab akibat Covid-19 yang kemudian melahirkan respon protokol yang men-downgrade aktivitas Masjid.

Ada beberapa hal yang perlu dilakukan oleh lembaga keagamaan untuk merespon kegelisahan masyarakat, karena dikawatirkan akan menyulut potensi kerumitan di masyarakat. Misalnya, lembaga keagamaan sudah waktunya untuk melakukan upaya dialog dengan pemerintah, melalui BNPB apakah sudah mungkin dibuat aturan zonaisasi daerah 
mana yang boleh ke Masjid dan daerah mana yang sebaiknya masyarakat tetap dirumah. Tidak dibuat generalisasi aturan untuk semua daerah, sementara fenomena daerah berbeda-beda. Harus ada penelitian ulang terhadap fenomena daerah yang masih memungkinkan adanya kegiatan ibadah, tentu dengan aturan yang ketat. Misalnya, kegiatan ibadah seperti Shalat Jama'ah diperuntukkan bagi warga sekitar Masjid yang memiliki tingkat kesehatan yang terjamin, seperti himbauan DMI.

Mungkin lembaga keagamaan perlu melakukan dan melibatkan pihak kedokteran yang memiliki otoritas terkait hal ini, untuk membantu melakukan pemetaan dan membangun argumentasi. Hal ini dilakukan untuk memberikan ketenangan kepada masyarakat, bahwa aktivitas ideologis mereka tidak terganggu, apalagi kebebasan melaksanakan ibadah dijamin oleh konstitusi. Ketenangan warga dilakukan untuk menumbuhkan daya imun warga, -yang boleh jadi karena lamanya kondisi seperti- justru akan menguras daya tahan tersebut. Penyebutan phisycal distanting, secara konsep kan sebenarnya interkasi dalam artian terbatas bisa dimaklumi, waktunya pendek, jaraknya terukur, media pertemuan selalu dilakukan penjegaan kesehatan dan lain-lain.

Satu aspek yang perlu juga diantisipasi adalah adanya dugaan ancaman pembubaran dan pasal pidana bagi masyarakat yang tetap melakukan keramaian sebagaimana maklumat Kapolri'. Terkait dengan keramaian, boleh jadi akan menyasar bentuk peribadatan warganegara Muslimin yang tetap melaksanakan Shalat jama'ah dan tarawih di Masjid. Jika ancaman ini benar, sudah seharusnya lembaga-lembaga keagamaan mengajak advokat yang peduli terhadap nasib ummat untuk ikut mengkaji dan melakukan advokasi. Sebagaimana yang terungkap dalam pemberitaan, adanya pengurus Masjid yang didatangi aparat pemerintahan dan pihak keamanan, sementara hak-hak warga belum terpenuhi secara nyata.

Terkait aspek pidana, dalam himbauan lembaga keagamaan belum dibahas dengan mendalam sebagai bentuk pembelaan atas hak dasar menjalankan ibadah. Para ahli sudah banyak yang berbicara, padahal himbauan pemerintah sebenarnya masih dalam kontek PSBB (Pembatasan Sosial Berskala Besar) yang syarat-syaratnya perlu diajukan ke Kemenkes RI yang didalamnya terdapat aspek zona epideminya.

\footnotetext{
${ }^{9}$ https://m.rri.co.id
} 
Sementara kita lihat dilapangan, terjadi generalisasi aturan ini dengan sangat masif sehingga membuat aparat dan masyarakat terpaksa "saling berhadap-hadapan". Aparat memilki keinginan untuk menegakkan aturan, sementara masyarakat ingin menjalankan kewajiban ideologisnya. Lembaga agama memang perlu melakukan antisipasi untuk menjembatani hal ini, karena satu sisi lembaga keagamaan adalah harapan masyarakat sebagai lembaga yang menyuarakan kepentingannya. Sementara pemerintah juga memerlukan keberadaan lembaga sebagai organ nonpemerintah yang menjadi penyangga negara. Artinya, pemerintah sebaiknya justru menggunakan potensi lembaga keagamaan untuk menjadi pemimpin dalam menyuarakan aspek-aspek ideologis yang memang tidak mudah untuk difahamai masyarakat, jika hal itu hanya disuarakan pemerintah. Apalagi suara pemerintah disertai ancaman pidana, maka dikawatirkan justru akan mengundang pembangkangan masal, apalagi masalahnya dalah konten idelogis.

Dalam penelitian ini, peneliti merasakan masih banyaknya keterbatasan bahan-bahan penelitian yang digunakan. Bahan-bahan tersebut terbatas pada hasil Fatwa dan himbauan dari lembaga keagamaan yang ada dalam situs resmi mereka. Peneliti tidak hadir pada paparan faktual yang dibuat dalam bentuk siaran pers dengan mengundang media. Penelitian ini juga subyektif dan terbatas karena hanya menyoroti lembaga keagamaan yang bersifat nasional dan berkedudukan di Jakarta, tidak memasukkan lembaga keagamaan yang lain. Pemilihan lembaga tersebut juga karena alasan dimungkinkan adanya kesamaan dalam ide dan juga meminimalisir bahasan sehingga tidak meluas.

Implikasi dari Fatwa MUI menjadikan hal-hal yang terkait dengan aspek ideologis menjadi lebih mudah untuk difahami secara keilmuan. MUI telah menempatkan posisinya pada kepemimpinan umat terkait sikap yang diambilnya. Sementara lembaga-lembaga keagamaan yang lainya, yang juga sebenarnya ada perwakilan di MUI khususnya di Majlis Fatwa mencukupkan diri pada memberikan penguat saja saat lembaga tersebut mengeluarkan himbauan dan pernyataaan sikapnya. Penyikapan yang ditunjukkan oleh lembaga keagamaan dengan menjadikan MUI sebagai pengelola isu sentral atas fenomena yang terjadi, menggambarkan adanya pola untuk menjadikan MUI sebagai rumah ummat Islam saat berhadapan dengan pemerintah. Dialog-dialog keumatan selanjutnya akan dimainkan melalui lembaga ini, sedang lembaga keagamaan yang lain 
memberikan penguat dan mendekatkan hasil fatwa kepada jama'ah yang menjadi binaannya.

Memang dengan fenomena Covid-19 inilah seharusnya menjadi pola yang konsisten saat masalah-masalah yang menyangkut keyakinan muncul ditengah ummat. Jika usaha memposisikan MUI sebagai rumah ummat berhasil, tentu akan memberikan bobot yang lebih nyata, untuk membuang kesan yang selama ini dirasakan seakan MUI terpisah kebijakannya dengan lembaga keagamaan. Jika diibaratkan seperti MUI adalah atapnya, sementara lembaga-lembaga keaagamaan adalah tingatinga penyangganya. Kedua-duanya penting dan negara memili kewajiban menjaga aset ini, dengan cara menjadikannya mitra aktif, bukan mitra pasif yang seakan hanya menjadi pelengkap penderita. Hanya diperlukan saat-saat tertentu saja.

\section{KESIMPULAN}

Melihat apa yang dilakukan lembaga keagamaan dengan menerbitkan surat himbauan ataupun pernyataan sikap, telah menggambarkan lembaga-lembaga tersebut tidak abai terhadap fenomena Covid-19. Walaupun dalam redaksinya berbeda, tapi pada aspek konten surat sudah menggambarkan tentang sesuatu yang perlu untuk segera dibangun. Perlunya dibangun kesadaran untuk menjaga kesehatan, persaudaraan dan ketersediaan pelayanan kesehatan Covid-19 sesuai kemampuan. Terdapat pola yang sama dari masing-masing lembaga untuk menempatkan hasil Fatwa MUI sebagai pondasi pijakan, kemudian dilanjutkan dengan penerbitan himbauan yang lebih teknis oleh masingmasing lembaga. Himbauan tersebut mengajak seluruh komponen unit dibawahnya untuk menyiapkan berbagai hal yang memungkin, akibat dampak Civid-19.

Ada satu implikasi yang berharga dari kasus ini, yaitu mulai berangsur-angsur menempatkan posisi MUI sebagai perekat dan penyatu ummat, khususnya dalam hal-hal yang bersinggungan dengan pemerintah. Jika pola hirarki menempatkan MUI sebagai dasar hukum dalam aspek yang luas, maka akan memudahkan persatuan umat kedepan. Pola seperti ini sebenarnya bukan kali pertama MUI mengambil peran dan lembaga mitra berpartisipasi, sudah banyak Fatwa yang telah diputuskan dan mendapat respon dukungan dari lembaga keagamaan. Tapi pada kali ini, 
karena fenomena masail fiqiyahnya berskala nasional, peran lembaga keagamaan juga semakin maksimal.

\section{DAFTAR PUSTAKA}

Burhan Bungin, Sosiologi Komunikasi, Kencana, Jakarta, 2008, cet. Ke-3

https://bnpb.go.id

https://dmi.or.id

https://mui.or.id

https://persis.or.id

https://www.alirsyad.or.id

https://www.nu.or,id

https://dewandakwah.or.id

https://m.rri.co.id 